\title{
Kandungan C-Organik, N-Total Tanah serta Hasil Padi Gogo (Oryza sativa L.) Akibat Perlakuan Pupuk Organik pada Ultisols Asal Desa Kentrong, Provinsi Banten
}

\author{
Rimma Rakhmalia*, Randy Gema R dan Anni Yuniarti \\ Fakultas Pertanian Universitas Padjadjaran \\ Jl. Raya Jatinangor Km. 21 Bandung 40600 \\ *Alamat korespondensi: rimma.rakhmalia@gmail.com
}

\begin{abstract}
Effect of Organic Fertilizers on C-organic, total-N soil and Yield of Upland Rice (Oryza sativa L.) on Ultisols Collected from Kentrong Area, Banten Province
\end{abstract}

This experiment was aimed to study the effect of various kinds and dosages of organic fertilizers on C-organic, total-N soil and yield of upland rice (Oryza sativa L.) in Ultisols collected from Kentrong area, Banten Province. The experiment was arranged in a randomized block design with ten treatments and three replications. The treatments were control (without organic ferlitizer), poultry manure $37.5 \mathrm{~g} /$ polibag, poultry manure $75 \mathrm{~g} /$ polybag, poultry manure $112.5 \mathrm{~g} /$ polybag, vermicomposting $37.5 \mathrm{~g} /$ polybag, vermicomposting $75 \mathrm{~g} /$ polybag, vermicomposting 112.5 g/polybag, compost of straw $37.5 \mathrm{~g} /$ polybag, compost of straw $75 \mathrm{~g} /$ polybag and compost of straw $112.5 \mathrm{~g} /$ polybag. The result showed that there was an effect of various kinds and dosages of organik fertilizers on C-Organic, but there was no effect on N-Uptake. For the yield of upland rice, dosage of $112.5 \mathrm{~g} /$ polybag of poultry manure gave the best result which was $21.08 \mathrm{~g} /$ polybag.

Keywords: C-organic, total-N, organic fertilizers

\begin{abstract}
ABSTRAK
Percobaan ini dilakukan untuk mengetahui pengaruh pemberian macam dan dosis pupuk organik terhadap C-organik, N-total dan hasil padi gogo (Oryza sativa L.) pada Ultisols asal Desa Kentrong, Provinsi Banten. Metode percobaan yang digunakan adalah Rancangan Acak Kelompok (RAK), dengan sepuluh perlakuan dan diulang tiga kali. Sepuluh taraf tersebut terdiri dari perlakuan kontrol (tanpa pupuk organik), pupuk kandang ayam 37,5 g/polibeg, pupuk kandang ayam 75 g/polibeg, pupuk kandang ayam 112,5 g/polibeg, pupuk kascing 37,5 g/polibeg, pupuk kascing 75 g/polibeg, pupuk kascing 112,5 g/polibeg, pupuk kompos jerami 37,5 g/polibeg, pupuk kompos jerami $75 \mathrm{~g} /$ polibeg, dan pupuk kompos jerami 112,5 g/polibeg. Hasil percobaan menunjukkan terdapat pengaruh pemberian macam dan dosis pupuk organik terhadap C-Organik tanah tetapi tidak berpengaruh terhadap N-Total. Untuk hasil panen padi gogo, dosis 112,5 g/polibeg pupuk kandang ayam memberikan hasil panen padi gogo terbaik yaitu 21,08 g/polibeg.
\end{abstract}

Kata kunci: C-organik, N-total, pupuk organik

\section{PENDAHULUAN}

Indonesia mempunyai lahan kering yang sangat luas yaitu sekitar 143.945 .000 ha. Menurut Badan Pusat Statistik tahun 2008, lahan kering secara umum berdasarkan penggunaan lahannya dapat dikelompokkan menjadi pekarangan, kebun, padang rumput, lahan sementara tidak dapat diusahakan, lahan untuk kayu-kayuan dan perkebunan dengan total luas mencapai 55.619.030 ha atau sekitar 29,4\% belum termasuk Maluku dan Papua. Salah satu ordo tanah yang mendominasi luas lahan kering yang potensial bagi pengembangan areal pertanian adalah Ultisols. Umumnya Ultisols mempunyai tingkat kesuburan tanah alami dari sangat rendah sampai rendah. Luas Ultisols meliputi 
45.796.000 ha atau 31,8\% dari luas total lahan kering di Indonesia (Hidayat \& Mulyani, 2002). Bahan induk dan iklim sangat memengaruhi tingkat kesuburan tanah Ultisols. Walaupun tingkat kesuburan Ultisols rendah, tetapi dengan pengelolaan yang tepat dan peranan teknologi yang disesuaikan dengan keadaan setempat maka diharapkan Ultisols dapat dimanfaatkan secara maksimal untuk pengembangan pertanian yang salah satunya adalah budidaya tanaman padi.

Pemanfaatan lahan kering untuk budidaya padi gogo sebagai alternatif pemenuhan kebutuhan beras nasional sampai saat ini masih rendah. Hal ini dapat terlihat dari masih rendahnya produksi padi gogo nasional tahun 2009 yang hanya mencapai 3,35 juta ton atau hanya 5,2 \% dari produksi total padi nasional sebesar 64,40 juta ton dengan tingkat produktivitas padi gogo sebesar 2,67 ton/ha. Produktivitas padi gogo di bawah produktivitas padi sawah yang mencapai 4,90 ton/ha (BPS, 2009). Menurut Prasetyo (2003), hambatan bertanam padi gogo mencakup keterbatasan lahan kering seperti kondisi lahan yang bergelombang, mudah tererosi, dan miskin unsur hara makro.

Luasnya Ordo Ultisols sangat potensial untuk dikembangkan menjadi lahan pertanian yang lebih produktif. Salah satu daerah penyebarannya terdapat di Kentrong, Provinsi Banten. Ultisols asal Desa Kentrong mempunyai C-Organik dan N-total tanah sedang sehingga nilai $\mathrm{C}: \mathrm{N}$ ratio tanahnya rendah. Upaya untuk meningkatkan $\mathrm{C}: \mathrm{N}$ ratio tanah Ultisol diantaranya dengan penambahan pupuk organik. Pupuk organik mempunyai pengaruh yang penting terhadap kesuburan tanah. Pupuk ini ramah terhadap lingkungan karena tidak terdapat residu kimia berbahaya seperti pada pupuk buatan. Bahan baku pembuatan pupuk organik sangat mudah ditemukan sehingga petani dapat memroduksinya sendiri.

Bahan organik adalah bahan yang berasal dari sisa-sisa makhluk hidup baik sisa tanaman maupun sisa hewan (Buckman \& Brady, 1982). Kompos merupakan salah satu bahan organik yang telah mengalami proses dekomposisi oleh mikroorganisme penguraisehingga dapat dimanfaatkan untuk memperbaiki sifat-sifat tanah. Limbah pertanian seperti jerami umumnya hanya dibabat dan dibakar sehingga jerami tersebut dapat dibuat menjadi kompos untuk menambah nilai guna dan penghematan biaya. Penggunaan kompos jerami dapat menambah ketersediaan unsur hara.

Pupuk organik lain yang digunakan dalam penelitian ini adalah pupuk kascing dan pupuk kandang ayam. Kascing sebagai bahan organik dapat meningkatkan kadar $\mathrm{N}, \mathrm{P}$ dan $\mathrm{K}$ di dalam tanah, menambah dan mempertahankan kandungan hara secara berkesinambungan, meningkatkan KTK, meningkatkan $\mathrm{pH}$ tanah, menurunkan keracunan $\mathrm{Al}$, meningkatkan laju infiltrasi, memperbaiki struktur tanah serta meningkatkan kadar bahan organik tanah (Tisdale et al., 1993). Pemberian pupuk organik yang digunakan dalam penelitian ini selain kascing dan kompos juga digunakan pupuk kandang ayam. Pupuk kandang mempunyai kemampuan mengubah berbagai faktor dalam tanah sehingga menjadi faktor-faktor yang menjamin meningkatnya kesuburan tanah (Sutedjo, 1995). Hasil pengujian pupuk kandang ayam yang digunakan dalam penelitian ini menunjukkan bahwa unsur hara yang terdapat didalamnya adalah 1,83\% $\mathrm{N} ; 0,79 \% \mathrm{P}$; dan 1,43\% K, dengan demikian dapat dikatakan bahwa nutrisi terbanyak yang dikandung pupuk kandang ayam adalah N. Selain itu, pupuk kandang ayam juga mengandung unsur-unsur hara mikro seperti Ca dan Mg. Penggunaan pupuk kandang ayam ini karena mudah didapatkan dan mengandung unsur $\mathrm{N}$ tiga kali lebih besar dari pada pupuk kandang lainnya (Hardjowigeno, 1995).

\section{BAHAN DAN METODE}

Penelitian dilaksanakan di rumah kaca dengan ketinggian tempat kurang lebih 780 meter di atas permukaan laut dan di Laboratorium Kesuburan Tanah, Fakultas Pertanian, Universitas Padjadjaran, Jatinangor, Kabupaten Sumedang, Provinsi Jawa Barat. Penelitian dilaksanakan dalam Rancangan Acak Kelompok (RAK) yang terdiri dari tiga macam pupuk organik dengan masing-masing tiga dosis perlakuan dan diulang sebanyak tiga kali. Berdasarkan perlakuan tersebut jumlah seluruh polibag adalah 10 × $3=30$ polibeg percobaan. Rancangan ini dibagi menjadi dua unit percobaan yaitu satu unit untuk pengamatan pada fase vegetatif akhir dan satu unit lagi digunakan untuk pengamatan hasil tanaman padi gogo pada fase generatif akhir sehingga jumlah keseluruhan 60 polibeg percobaan.

Perlakuan yang diberikan yaitu macam dan dosis pupuk organik satu unit percobaan digunakan untuk analisis destruksi diantaranya $\mathrm{C}$ organik dan $\mathrm{N}$ total pada umur vegetatif akhir tanaman (60 HST). Unit kedua digunakan untuk analisis hasil panen pada umur 120 HST. Perlakuan tersebut adalah tanpa pemberian pupuk organik (kontrol); pupuk kandang ayam 7,5 ton/ha setara dengan 37,5 g/polibeg; pupuk kandang ayam 15 ton/ha setara dengan $75 \mathrm{~g} /$ polibeg; pupuk kandang ayam 22,5 
ton/ha setara dengan 112,5 g/polibeg; pupuk kascing 7,5 ton/ha setara dengan 37,5 g/polibeg; pupuk kascing 15 ton/ha setara dengan 75 g/polibeg; pupuk kascing 15 ton/ha setara dengan 112,5 g/polibeg; pupuk kompos jerami 7,5 ton/ha setara dengan 37,5 g/polibeg. Pupuk kompos jerami 15 ton/ha setara dengan $75 \mathrm{~g} /$ polibeg; dan pupuk kompos jerami 22,5 ton/ha setara dengan 112,5 g/polibeg.

Tanah yang digunakan untuk media tanam dalam penelitian ini adalah contoh tanah Ultisols asal Desa Kentrong, Provinsi Banten. Tanah yang diambil merupakan tanah lapisan olah pada kedalaman 0-20 cm dari permukaan tanah. Tanah diambil secara komposit lalu dicampur sampai homogen, dikeringudarakan lalu disaring dengan menggunakan ayakan berdiameter $5 \mathrm{~mm}$, kemudian tanah ditimbang masing-masing sebanyak $9,8 \mathrm{~kg}$ setiap polibeg. Tiap polibeg tersebut tanahnya dicampur dengan pupuk organik sesuai dengan macam dan dosis perlakuan. Setelah itu, dua buah pipa paralon yang berdiameter satu sentimeter diletakkan di sebelah kiri-kanan polibeg yang berguna untuk penyiraman, kemudian diinkubasikan selama dua minggu yang bertujuan agar pupuk organik terdekomposisi dengan baik. Selama masa inkubasi media tanam tersebut disiram sampai kapasitas lapang.

Pupuk tunggal anorganik yang digunakan sebagai pupuk dasar antara lain urea, SP-18 dan $\mathrm{KCl}$ dengan dosis sebagai berikut: pupuk urea $(46 \% \mathrm{~N})$ dengan dosis $75 \mathrm{~kg} / \mathrm{ha}$ urea setara dengan 1,33 g/polibeg urea, pupuk SP-18 (18\% $\left.\mathrm{P}_{2} \mathrm{O}_{5}\right)$ dengan dosis $150 \mathrm{~kg} / \mathrm{ha}$ SP-18 setara dengan $0,5 \mathrm{~g} /$ polibeg
SP-18, dan pupuk $\mathrm{KCl}\left(60 \% \mathrm{~K}_{2} \mathrm{O}\right)$ dengan dosis 75 $\mathrm{kg} / \mathrm{ha} \mathrm{KCl}$ setara dengan $0,8 \mathrm{~g} /$ polibeg $\mathrm{KCl}$.

Pengambilan sampel tanah dilakukan pada fase vegetatif akhir (12 MST) yang ditandai dengan munculnya primordia bunga dan batang padi atau tanaman memasuki fase bunting malai. Pemanenan hasil padi dilakukan pada saat tanaman mencapai kriteria masak kuning, yaitu $80 \%$ malai sudah menguning dan gabah sudah keras (Prasetyo, 2003), kondisi ini tercapai pada fase generatif akhir. Pemanenan dilakukan dengan memotong malai menggunakan sabit dan selanjutnya gabah dipisahkan dari malainya.

\section{HASIL DAN PEMBAHASAN}

\section{C-organik Tanah}

Hasil analisis statistik menunjukkan adanya pengaruh yang nyata terhadap C-Organik tanah akibat pemberian dosis dan macam pupuk organik. Pemberian $75 \mathrm{~g} /$ polibeg dan 112,5 g/polibeg pupuk kandang ayam memberikan pengaruh yang berbeda terhadap nilai C-organik tanah jika dibandingkan dengan kontrol (Tabel 1). Hal tersebut diduga karena pupuk kandang ayam memiliki kandungan C-Organik lebih tinggi yaitu $24,83 \%$ bila dibandingkan dengan pupuk lainnya. Pemberian pupuk kandang ayam pada dosis 112,5 g/polibeg memberikan nilai C-organik yang tinggi sebesar $4,08 \%$. Hal tersebut dikarenakan pupuk yang berasal dari ayam jenis pedaging ini memiliki kadar C organik yang relatif tinggi.

Tabel 1. Pengaruh macam dan dosis pupuk organik terhadap C-Organik.

\begin{tabular}{lc}
\hline Perlakuan & C-Organik (\%) \\
\hline Tanpa perlakuan (kontrol) & $2,21 \mathrm{a}$ \\
Pupuk kandang ayam 37,5 g/polibeg & $2,80 \mathrm{abc}$ \\
Pupuk kandang ayam 75 g/polibeg & $3,58 \mathrm{bcd}$ \\
Pupuk kandang ayam 112,5 g/polibeg & $4,08 \mathrm{~d}$ \\
Pupuk kascing 37,5 g/polibeg & $2,61 \mathrm{ab}$ \\
Pupuk kascing 75 g/polibeg & $3,05 \mathrm{abcd}$ \\
Pupuk kascing 112,5 g/polibeg & $2,64 \mathrm{ab}$ \\
Pupuk kompos jerami 37,5 g/polibeg & $2,85 \mathrm{abcd}$ \\
Pupuk kompos jerami 75 g/polibeg & $3,58 \mathrm{bcd}$ \\
Pupuk kompos jerami 112,5 g/polibeg & $3,93 \mathrm{~cd}$ \\
\hline
\end{tabular}

Keterangan: Angka yang diikuti dengan huruf yang sama tidak berbeda nyata menurut Uji Jarak Berganda Duncan pada taraf $5 \%$.

Faktor penyusun pupuk kandang ayam ini dipengaruhi oleh jenis konsentrat yang diberikan dan juga dipengaruhi oleh sekam yang digunakan sebagai alas kandang. Kedua faktor tersebut yang 
akan memberikan tambahan sumbangan hara ke dalam tanah. Kotoran ayam yang bercampur dengan sisa pakan dan alas kandang menjadikan pupuk organik ini kaya akan unsur hara. Pupuk kandang ayam ini memiliki asam-asam organik yang baik, dan sekam memberikan tambahan bahan organik ke dalam tanah. Hal ini mengakibatkan C-organik semakin bertambah.

Tabel 2. Pengaruh macam dan dosis pupuk organik terhadap N-Total.

\begin{tabular}{lc}
\hline Perlakuan & N-Total (\%) \\
\hline Tanpa perlakuan (kontrol) & $0,30 \mathrm{a}$ \\
Pupuk kandang ayam 37,5 g/polibeg & $0,33 \mathrm{a}$ \\
Pupuk kandang ayam 75 g/polibeg & $0,30 \mathrm{a}$ \\
Pupuk kandang ayam 112,5 g/polibeg & $0,31 \mathrm{a}$ \\
Pupuk kascing 37,5 g/polibeg & $0,41 \mathrm{a}$ \\
Pupuk kascing 75 g/polibeg & $0,35 \mathrm{a}$ \\
Pupuk kascing 112,5 g/polibeg & $0,37 \mathrm{a}$ \\
Pupuk kompos jerami 37,5 g/polibeg & $0,37 \mathrm{a}$ \\
Pupuk kompos jerami 75 g/polibeg & $0,40 \mathrm{a}$ \\
Pupuk kompos jerami 112,5 g/polibeg & $0,35 \mathrm{a}$ \\
\hline
\end{tabular}

Keterangan: Angka yang diikuti dengan huruf yang sama tidak berbeda nyata menurut Uji Jarak Berganda Duncan pada taraf $5 \%$.

Tabel 3. Pengaruh macam dan dosis pupuk organik terhadap bobot gabah kering panen (GKP).

\begin{tabular}{lc}
\hline Perlakuan & Bobot GKP (g/polibeg) \\
\hline Tanpa perlakuan (kontrol) & $9,33 \mathrm{a}$ \\
Pupuk kandang ayam 37,5 g/polibeg & $15,88 \mathrm{~b}$ \\
Pupuk kandang ayam 75 g/polibeg & $17,23 \mathrm{~b}$ \\
Pupuk kandang ayam 112,5 g/polibeg & $21,08 \mathrm{~cd}$ \\
Pupuk kascing 37,5 g/polibeg & $17,63 \mathrm{bc}$ \\
Pupuk kascing 75 g/polibeg & $17,88 \mathrm{bc}$ \\
Pupuk kascing 112,5 g/polibeg & $24,00 \mathrm{~d}$ \\
Pupuk kompos jerami 37,5 g/polibeg & $16,22 \mathrm{~b}$ \\
Pupuk kompos jerami 75 g/polibeg & $19,12 \mathrm{bc}$ \\
Pupuk kompos jerami 112,5 g/polibeg & $19,93 \mathrm{bc}$ \\
\hline
\end{tabular}

Keterangan: Angka yang diikuti dengan huruf yang sama tidak berbeda nyata menurut Uji Jarak Berganda Duncan pada taraf $5 \%$.

\section{N-total Tanah}

Hasil analisis statistik menunjukkan terdapat pengaruh yang tidak nyata terhadap $\mathrm{N}$-total tanah akibat pemberian pupuk organik (Tabel 2). Pemberian macam dan dosis pupuk organik tidak berbeda nyata dengan kontrol disebabkan oleh Ultisols mengandung $\mathrm{Fe}$ dan $\mathrm{Al}$ yang tinggi serta $\mathrm{pH}$ masam, sehingga penguraian bahan organik berjalan lambat (Hardjowigeno, 1995). Selain itu, N dapat hilang dari dalam tanah akibat diserap tanaman, menguap dalam bentuk gas terutama pada temperatur lingkungan yang tinggi maupun terikat oleh liat.

\section{Bobot Gabah Kering Panen (GKP)}

Hasil uji statistik menunjukkan terdapat pengaruh yang berbeda dari perlakuan pupuk organik terhadap bobot gabah kering panen (GKP) yang disajikan pada Tabel 3. Pemberian dosis pupuk organik 37,5 g/polibeg, $75 \mathrm{~g} /$ polibeg, dan $112,5 \mathrm{~g} /$ polibeg dari masing-masing macam pupuk organik berpengaruh terhadap hasil gabah kering panen padi gogo. Bobot gabah kering giling tanaman 
padi gogo sendiri dipengaruhi oleh jumlah anakan produktif dan jumlah malai produktif. Hasil panen tanaman padi gogo tertinggi diperoleh dari perlakuan 112,5 g/polibeg kascing dan pupuk kandang ayam yaitu masing-masing $24 \mathrm{~g} /$ polibeg setara dengan 4,8 ton/ha dan 21,08 g/polibeg setara dengan 4,22 ton/ha.

\section{SIMPULAN}

Pemberian macam dan dosis pupuk organik berpengaruh terhadap C-organik tetapi tidak berpengaruh terhadap $\mathrm{N}$ total. Dosis 112,5 g/polibeg atau setara dengan 22 ton/ha pupuk kandang ayam memberikan hasil panen padi gogo tertinggi yaitu sebanyak $24 \mathrm{~g} /$ polibeg atau setara dengan 4,8 ton/ha.

\section{DAFTAR PUSTAKA}

Hidayat, A dan A Mulyani. 2002. Lahan Kering untuk Pertanian. Teknologi Pengelolaan Lahan Kering: Menuju Pertanian Produktif dan Ramah Lingkungan. PP dan PT dan
Agklim. Badan Penelitian dan Pengembangan Pertanian-Departemen Pertanian. 1: 1-34.

Badan Pusat Statistik. 2008. Luas Lahan Pertanian. Tersedia online pada www.bps.go.id. Diakses tanggal 15 Juli 2014.

Buckman, HO and NC Brady. 1982. The Nature and Properties of Soil. The Mac Millan Co. New York.

Hardjowigeno, S. 1995. Ilmu Tanah. Akademika Pressindo. Jakarta.

Prasetyo, YT. 2003. Bertanam Padi Gogo Tanpa Olah Tanah. Penebar Swadaya. Jakarta.

Sutedjo, MM. 1995. Pupuk dan Cara Pemupukan. Rineka Cipta. Jakarta.

Tisdale, SL, WL Nelson, JD Beaton and JL Havlin. 1993. Soil Fertility and Fertilizer. $5^{\text {th }}$ Ed. Macmillan Publishing Company. New York. 


\title{
Uji Keefektifan Antijamur Ekstrak Air Rimpang Lengkuas (Alpinia galanga [L] Willd.) sebagai Perlakuan Pratanam untuk Mengendalikan Colletotrichum spp. pada Kedelai (Glycine max L.)
}

\author{
Endah Yulia ${ }^{{ }^{*}}$, Tarkus Suganda ${ }^{1}$, Fitri Widiantini ${ }^{1}$ dan Rangga Irawan Prasetyo ${ }^{2}$ \\ ${ }^{1}$ Departemen Hama dan Penyakit Tumbuhan, Fakultas Pertanian, Universitas Padjadjaran \\ Jl. Raya Bandung-Sumedang KM 21, Jatinangor 40600 \\ ${ }^{2}$ Alumni Departemen HPT, Fakultas Pertanian, Universitas Padjadjaran \\ *Alamat korespondensi: endah.yulia@unpad.ac.id
}

\begin{abstract}
Antifungal Effect of Aqueous Extract of Galangal (Alpinia galanga [L] Willd.) Rhizome as Seed Treatment to Control Colletotrichum spp. of Soybean (Glycine max L.)
\end{abstract}

Colletotrichum is one of the most important seed-borne pathogens of soybean which is usually controlled with synthetic fungicide seed treatment. However, it is believed that the use of synthetic fungicide can cause a variety of negative impacts to the environment and human health. Galangal rhizome extract has been widely reported to have antifungal and antibacterial properties. The aim of the study was to investigate the effectiveness of galangal rhizome aqueous extract as antifungal for pre-planting seed treatment to control Colletotrichum spp. in soybean. Laboratory and glasshouse experiments were carried out at the Department of Plant Pests and Diseases, Faculty of Agriculture, Universitas Padjadjaran. The method used was an experimental method to test the effectiveness of galangal rhizome aqueous extract against the emergence and spore germination suppression of Colletotrichum spp., and to test the seed viability and plant growth of soybean. Galangal rhizome extract with concentrations of $10 \%$, $30 \%, 50 \%, 70 \%, 90 \%$ and $100 \%$ as well as a metalaxyl fungicide $(0.5 \mathrm{~g} / \mathrm{l})$ were applied as a seed treatment. The results showed galangal rhizome aqueous extract at concentration of $100 \%$ reduced the presence of Colletotrichum spp. in seeds up to $100 \%$ after the treatment and suppressed the spore germination by $76.20 \%$ as well as increased the seed viability and the growth of soybean plants.

Keywords: Alpinia galanga, aqueous extract, seed treatment, soybean, Colletotrichum spp.

\begin{abstract}
ABSTRAK
Umumnya pengendalian penyakit tular benih pada kedelai dilakukan melalui perlakuan benih dengan menggunakan fungisida sintetik yang diakui dapat menimbulkan berbagai dampak negatif pada lingkungan maupun kesehatan manusia. Penggunaan ekstrak air rimpang lengkuas untuk perlakuan benih dapat diterapkan sebagai alternatif pengendalian penyakit tular benih pada kedelai. Lengkuas telah banyak dilaporkan memiliki sifat antijamur dan antibakteri. Penelitian ini dilaksanakan dengan tujuan untuk mengetahui keefektifan ekstrak air rimpang lengkuas sebagai antijamur untuk perlakuan benih dalam mengendalikan penyakit tular benih pada kedelai. Percobaan dilaksanakan di Laboraturium Fitopatologi dan rumah kaca Departemen Hama dan Penyakit Tumbuhan, Fakultas Pertanian, Universitas Padjadjaran. Metode penelitian yang digunakan adalah metode eksperimen dengan pengujian keefektifan air persaan rimpang lengkuas terhadap kemunculan, penekanan perkecambahan konidia, uji pertumbuhan benih, dan viabilitas benih jamur Colletotrichum spp. pada kedelai. Ekstrak air rimpang lengkuas dengan konsentrasi $10 \%$; 30\%; 50\%; 70\%; 90\%; dan 100\% serta fungsida berbahan aktif metalaksil $(0,5 \mathrm{~g} / \mathrm{l})$ diaplikasikan sebagai perlakuan benih kedelai. Hasil percobaan menunjukkan ekstrak air rimpang lengkuas konsentrasi 100\% dapat menekan sampai 100\% kemunculan Colletotrichum spp. setelah
\end{abstract}

